\title{
Seismic Risk Analysis for Critical Infrastructure: The Case Study of a Medical Center and its Supporting Systems in Yangon, Myanmar
}

\author{
Khin Aye Mon ${ }^{1 *}$, Kyaw Kyaw ${ }^{1}$, Zin Mar Lar Tin San ${ }^{1}$, Junji Kiyono ${ }^{2}$, Takeshi Koike ${ }^{3}$, Aung Htet ${ }^{1}$, \\ Chit Nyein Aye ${ }^{1}$, Yin New Oo ${ }^{1}$ \\ ${ }^{I}$ Dept. of Civil Engineering, Yangon Technological University, Yangon, Myanmar. \\ ${ }^{2}$ Dept. of Urban Management, Kyoto University, Kyoto, Japan. \\ ${ }^{3}$ Professor of Kyoto University (retired), Academic Advisor of JICA EEHE PROJECT, Yangon, Myanmar.
}

"Corresponding author: khinayemon.civil@gmail.com

\begin{abstract}
Myanmar has a great strike-slip active fault called the "Sagaing Fault Zone" besides the SumatraAndaman Subduction Zone. Major cities (Yangon, Naypyitaw, Bago and Mandalay) are at risk along this fault. Recently, in 2012, Thabeikkyin earthquake with Magnitude of 6.8 caused collapse of many residential housings and ground failures near Mandalay. Therefore more attention should be paid for Yangon which has no large earthquakes since 1930 and is the largest not only in population but also in socio-economic activity. One of the most important concerns after an earthquake is to survive under any disastrous conditions. The medical care is requested not only for emergent injured people after an earthquake, but also for various types of patient and aged people from several weeks to longer periods. So medical center must be always functional before and after earthquake. For this purpose, medical buildings should be structurally resilient and also be functional for medical services by sustainable supply of electric power, water and any other delivery service which can be carried out by urban lifeline systems. This research is to investigate the structural vulnerability of hospital buildings and facilities, to assess the performance of urban lifeline systems and to check the operational capability of medical services in which surgical capability and life safety management method should be discussed. The water supply system is adopted as a typical lifeline system in Yangon in this study. One sample medical center in Yangon is adopted to carry out this analysis. Finally, the performance of medical services after the earthquakes can be assessed in a probabilistic manner.
\end{abstract}

Keywords—vulnerability assessment, performance, hospital building, lifeline system, medical service, fault.

\section{INTRODUCTION}

$\mathrm{M}$ yanmar is earthquake-prone area and has many active faults as shown in Figure 1. Among them, Sagaing fault is a great strike-slip fault and passes through populated cities. This fault has the return period of 50 to 80 years. Yangon which is the biggest city and has highest density of population in Myanmar, is located at $50 \mathrm{~km}$ far from the epicentre along the Sagaing fault. It frequently experiences to earthquakes in various intensities.

In Yangon, most of the hospital buildings and their related supporting facilities were designed and built since the seismic design guideline had not been established. These structures are potentially vulnerable for future earthquakes and medical serviceability might be difficult to maintain in the minimum requirement level immediately after the earthquake.

One of the most important concerns after an earthquake is to survive under any disastrous conditions. The medical care is requested not only for emergent scene immediately after the earthquake, but also for various types of injured, patient and aged people from several weeks to longer periods. Therefore the functionality of hospital system after earthquakes is of vital importance.

Hospital system is supported by various supporting and lifeline facilities. The functionality of supporting system in a hospital has a considerable effect on the functionality of the main hospital buildings. The supporting system includes water supply system, electricity system and fire system. The water supply system and pipeline network which must be structurally resilient and functional after earthquakes should have as the same target performance levels as the main hospital buildings.

In the present water supply system of Yangon which has been operated over 100 years, all pumping in reservoirs and main transmission pipes have already aged and beyond its life span. As a result, almost 50\% water leakage loss is estimated. Seismic design guideline, however, has not been established not only for pipes but also any supporting facilities related to the water supply system.

This research is to investigate the structural vulnerability of hospital buildings and facilities, to assess the performance of urban lifeline systems and to check the operational capability of medical services. Schematic illustration of study area is shown in Figure 2.

As a case study, among the hospitals in Yangon, Thingangyun (Sanpya) hospital (shown in Figure 3.) is selected depending on not only the medical requirements of the local people but also soft soil conditions in 
August $1^{\text {st }}-2^{\text {nd }}$ 2017, Surabaya - Indonesia

Thingangyun Township. Site plan of the hospital including water supply system is shown in Figure 4.

In this study, according to the three earthquake levels of probability of exceedance $50 \%, 10 \%$ and $2 \%$ in 50 years such as Maximum Operational Earthquake (MOE), Design Basis Earthquake (DBE) and Maximum Considered Earthquake (MCE), the damage of buildings and water supply facilities can generally be three stages: Immediate Occupancy (IO), Level of Safety (LS) and Collapse Prevention (CP).

\section{METHOD}

Existing condition of site data, earthquake hazard data, structures data, water lifeline data are collected. The case study hospital was constructed in 1991 so the design of structures for existing condition is carried out without considering the seismic loading on the basis of older code ACI 318-99. Nonlinear static pushover analysis based on ATC-40 capacity spectrum method and FEMA 356 is used to evaluate the performance -based safety assessment of buildings. SAP 2000 vs. 14 is used to perform the pushover analysis of supporting buildings.

Safety assessment of pipelines is based on seismic design calculations developed by response displacement method in the critical urban infrastructure handbook. By checking SPT value from the collection of the soil bore hole test data, the soil profile types existing along the pipeline under study area are chosen based on the code, ATC-40.

Seismic Vulnerability Assessment is carried out by using the following procedures:

1) Firstly, the site soil data and supporting building information are collected.

2) The seismic hazard analysis for MOE, DBE and MCE is carried out for Thingangyun (Sanpya) hospital site. The peak ground acceleration at the bed rock is evaluated.

3) The bore hole test and microtremor test are carried out at the hospital campus. The soil amplification factors of surface soil strata for three earthquake levels are estimated by using the method developed by INOUE et al.

4) The peak ground accelerations at surface are evaluated.

5) Depending upon existing conditions, modeling of main hospital building, supporting structures, and water supply system in the campus and along lifeline are carried out.

6) For main hospital building and supporting structures, safety assessment to comply the required performance is performed by using pushover analysis. Safety assessment of pipelines is performed by using seismic design calculations developed by response displacement method.

7) Probability of failure of each component are evaluated and finally the vulnerability function of the whole system is developed.

\section{A. Seismic Hazard Analysis}

The seismic hazard analysis for three earthquake levels is determined by the probabilistic seismic hazard analysis
(PSHA). The estimated seismic hazard levels are based on the seismic hazard assessment for Myanmar developed by Myanmar Earthquake Committee (MEC) and Myanmar Geosciences Society (MGS) and bounded Gutenberg-Richter recurrence law [3].

Only Sagaing fault is considered as a line source. The cumulative probability distribution function of moment magnitudes is estimated by

$$
\mathrm{F}_{\mathrm{M}}\left(\mathrm{m}_{\mathrm{j}}\right)=\frac{1-10^{-\mathrm{b}\left(\mathrm{M}-\mathrm{M}_{\min }\right)}}{1-10^{-\mathrm{b}\left(\mathrm{M}_{\max }-\mathrm{M}_{\min }\right)}}
$$

where $F_{M}\left(m_{j}\right)$ is cumulative probability distribution function; $M$ is moment magnitude; $b$ is constant.

Probability of occurrence of discrete set of magnitudes is determined by

$$
P\left(M=m_{j}\right)=F_{M}\left(m_{j+1}\right)-F_{M}\left(m_{j}\right)
$$

The annual rate of exceedance curve as a function of corresponding moment magnitudes for Sagaing fault is presented in Figure 5.

An earthquake level is defined with a probability of being exceeded in a specific period.

For MOE: $50 \%$ in 50 years

For DBE: $10 \%$ in 50 years

For MCE: $2 \%$ in 50 years

The return periods of three levels of earthquake can be calculated by

$$
\mathrm{T}=\frac{1}{1-(1-\mathrm{P})^{1 / n}}
$$

Then, the probability of occurrence in any year for each earthquake level can be calculated by $\mathrm{T}=\frac{1}{\mathrm{P}}$. After that the associated magnitudes for three earthquake levels are estimated using Figure 5.

After that the peak ground acceleration (PGA) at bed rock can be estimated using the following equation:

$$
\ln \mathrm{PGA}=-0.152+0.859 \mathrm{M}-1.803 \ln (\mathrm{R}+25)(4)
$$

where, PGA is peak ground acceleration $(\mathrm{g})$; $\mathrm{M}$ is moment magnitude; $\mathrm{R}$ is epicentral distance from the source $(\mathrm{km})$. The calculated results are described in

\section{Table 1.}

\section{B. Ground Motion Parameter s Evaluation}

Thingangyun (Sanpya) hospital is underlying the alluvial deposits. To investigate the soil conditions of the selected area, bore hole test and microtremor test are carried out. Based on the test results, the nonlinear soil amplification factor is evaluated.

Finally, the peak ground accelerations at ground surface for three earthquake levels are calculated by using:

$$
G_{\mathrm{s}}(\mathrm{T})=\frac{\mathrm{PGA}_{\mathrm{s}}}{\mathrm{PGA}_{\mathrm{b}}}
$$


August $1^{\text {st }}-2^{\text {nd }}$ 2017, Surabaya - Indonesia

where, $G_{s}(T)$ is soil amplification factor of the site; $(\mathrm{PGA})_{\mathrm{b}}$ is peak ground acceleration at bed rock; $(\mathrm{PGA})_{\mathrm{s}}$ is peak ground acceleration at ground surface

From probabilistic seismic hazard analysis, the estimated moment magnitudes, peak ground acceleration at surface in which correspond to MOE, DBE and MCE are summarized in Table $\mathbf{1 .}$

\section{Structural Safety Assessment}

The safety assessment of structures and water supply system is conducted in three parts as (i) safety assessment of main hospital building and supporting buildings, (ii) safety assessment of pipeline network and (iii) water lifeline system.

\section{(1) Main hospital building and supporting buildings}

\section{(1.1)Building configurations}

In main hospital building, A block is two-storeyed and B, C, D blocks are three-storeyed R.C building with brick walls (Figure 4.). The 3D modeling of the building is shown in Figure 6. For assessment, the building is divided into four sections as described in Table 2.

The supporting buildings for water supply system include underground water tank, pump house, elevated water tank and ground tank. The configurations of these structures are different in terms of height, existing conditions, locations, function, and their seismic resiliency. Pump house, elevated water tank and ground tank are above-ground structures whereas underground tank is under-ground structure. All the supporting structures are assumed to be reinforced concrete structures. Modeling of these structures are shown in Figure 7 to 11.

Material properties used are 3000 psi (20.684 MPa) for concrete strength $\left(\mathrm{f}_{\mathrm{c}}{ }_{\mathrm{c}}\right)$ and $50000 \mathrm{psi}(344.738 \mathrm{MPa})$ for rebar strength $\left(f_{y}\right)$.

\section{(1.2) Safety assessment of buildings}

From performance point of pushover analysis, the maximum inelastic displacement of the structures can be obtained to assess the safety to comply the performance requirements. The critical displacements of supporting framed buildings are considered as $1 \%$ of total height for IO under MOE, $2 \%$ of total height for LS under DBE, and $4 \%$ of total height for CP under MCE. The critical displacements of supporting wall structures are $0.5 \%$ of total height for IO, $1 \%$ of total height for LS, and $2 \%$ of total height for CP respectively based on FEMA 356 [7].

The probability of failure is evaluated by using the maximum inelastic displacement obtained from the pushover analysis and the critical displacement according to FEMA 356. It is calculated by the following equation:

$$
\begin{aligned}
\mathrm{P}_{\mathrm{f}} & =\mathrm{P}[\mathrm{Z}<0 \mid \mathrm{EQ}] \\
\mathrm{P}_{\mathrm{f}} & =\mathrm{P}\left[\text { Capacity }^{\mathrm{EQ}}<\text { Demand }^{\mathrm{EQ}} \mid \mathrm{EQ}\right] \\
\mathrm{P}_{\mathrm{f}} & =\mathrm{P}\left[\mathrm{u}_{\mathrm{cr}}^{\mathrm{EQ}}<\mathrm{u}_{\max }^{\mathrm{EQ}} \mid \mathrm{EQ}\right] \\
& =1-\phi\left[\frac{\mathrm{u}_{\mathrm{cr}}-\mathrm{u}_{\max }}{\sqrt{\sigma_{\mathrm{cr}}^{2}+\sigma_{\max }^{2}}}\right]
\end{aligned}
$$

where, $\mathrm{P}_{\mathrm{f}}$ is probability of failure; $\mathrm{Z}$ is demand capacity; EQ is earthquakes; $u_{c r}^{\mathrm{EQ}}$ is critical displacement for a certain limit state; $u_{\max }^{\mathrm{EQ}}$ is maximum displacement due to a certain earthquake; $\sigma$ is standard deviation; $\mu$ is mean value and $\phi$ is standard normal distribution. The fragility curves of hospital building and its supporting structures are shown in Figure 14 to 21.

(2) Water supply system in hospital campus and lifeline system

\section{(2.1) Pipeline configurations in hospital campus}

The pipelines in the system are different in material used, depth, and length of segment. The types of materials are cast iron (CI) and polyvinyl chloride (PVC). The life span of CI and PVC can be assumed as 75 to 100 years so that the existing pipeline can be assumed as newtyped joints. But the design of these existing pipelines was not performed for seismic load case. Therefore it will take considerable to replace all of them for future earthquakes. Replacing all of these types of joint will require an enormous investment. Therefore, it is necessary to consider a partial and selective retrofitting scheme. Performance-based safety assessment of existing pipelines is necessary for the retrofitting scheme.

All the connection types between the two segments are mechanical joint and the failure mode of this type of joint is due to excessive joint axial displacement. Therefore, in this study, the safety assessment of water pipelines is carried out in terms of joint axial displacement. The existing conditions of pipelines and joints are shown in Figure 12 (a).

\section{(2.2) Water lifeline system along the study area}

The study area is along the path from Water lifeline system along study area Ngamoeyeik reservoir to Nyaung $\mathrm{Na}$ Pin water treatment plant and then to Thingangyun (Sanpya) Hospital. The reservoir is constructed in 1995 and is kind of open channel. Another water source, Gyobyu reservoir, is linked to the pipeline for non-occurrence of water shortage due to emergency condition.

To reach out the water to target area, water lifeline pass through four townships: Mingalardon, North Oakkalarpa, South Oakkalarpa, and Thingangyun. Along the path, various types and diameter of pipes such as mild steel pipe (MS), pressurized concrete pipe (PCP), high density polyethylene pipes (HDPE), cast iron pipe (CI), and poly vinyl chloride pipe (PVC) are used. The connection types between the two pipes are used as both mechanical and continuous joints.

Schematic configuration and modelling of existing water supply pipeline are shown in Figure 13.

\section{(2.3) Safety assessment of water pipelines}

In the safety assessment of pipelines, the horizontally travelling seismic waves that are transmitted to the incident angle of 45 degree to the pipelines are considered as seismic load. The seismic performance of the pipes are assessed by seismic design guideline from Japan Water Work Association (JWWA).

In joint axial displacement calculation process, the soil 
August $1^{\text {st }}-2^{\text {nd }}$ 2017, Surabaya - Indonesia

properties, the material properties and detail measurement of pipes, and the seismic loads are taking into account. For seismic case, spectral velocity is used as a demand parameter in the calculation of ground response. This value for study area are shown in Table 3 .

For knowing the probability of failure of each pipe, the fragility curves of each pipe segment (shown in Figure 12(b) and Figure 13(b)) are developed as a function of spectral acceleration. The fragility curves are developed using the displacements obtained from pushover analysis and joint axial displacement calculation for various spectral accelerations.

The probability of failure of a segment can be determined by:

$$
\mathrm{P}_{\mathrm{f}}=1-\prod_{\mathrm{j}=1}^{\mathrm{N}}\left\{1-\mathrm{P}\left[\Delta_{\mathrm{cr}}^{\mathrm{EQ}}<\Delta_{\max }^{\mathrm{EQ}} \mid \mathrm{EQ}\right]\right\}
$$

The developed fragility curves for water pipe lines are shown in Figure 22 to 26.

\section{RESULTS AND DISCUSSION}

In this study the vulnerability of a structure is expressed in terms of probability of failure. The vulnerability conditions are shown in Table 4. Based on these conditions, the following can be concluded:

For main hospital building-

1. Section 3 and 4 are more vulnerable than other sections.

2. The whole structure need to retrofit to withstand under DBE earthquake level.

3. But the building may not be resisted under MCE earthquake level.

4. The building should be retrofitted and rehabilitated.

For supporting structures-
1. The two underground tanks are not vulnerable to future earthquakes and has highest reliability than other supporting buildings.

2. The most vulnerable structure is elevated water tank.

3. Pump house and elevated water tank should be retrofitted to withstand under MOE, DBE and MCE earthquake levels.

For water supply system in the campus

1. It is found that mechanical joints are very vulnerable to earthquakes. So pipe joints are the weakest points in the system.

2. Almost all the pipe joints will fail their target performances with the probability of failure of greater than $80 \%$ under three earthquake levels. So retrofitting of pipe joints is required.

3. The water supply system in Thingangyun hospital is very vulnerable to earthquake since it is a series system.

4. For future earthquakes, the existing system should be retrofitted.

For water lifeline system along study area

1. All mechanical joint pipes have $100 \%$ probabilities of failure in three seismic levels whereas the continuous ones have no failure stages under MOE and DBE earthquake levels.

2. The probability of connectivity at each link for the whole network has a weak point because it will not be sure to get enough water if the pipelines are existing as far as away from the source.

3. This shows that the alert for aging pipes, especially mechanical joint pipes, should be replaced with newly developed pipes based on seismic design guideline. 
The Third International Conference on Civil Engineering Research (ICCER)

August $1^{\text {st }}-2^{\text {nd }}$ 2017, Surabaya - Indonesia

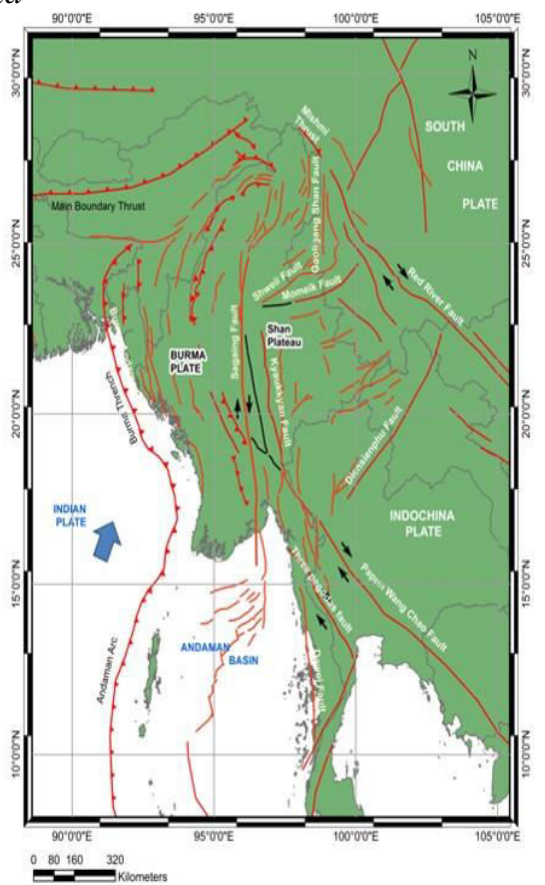

Figure 1. Myanmar map with active faults

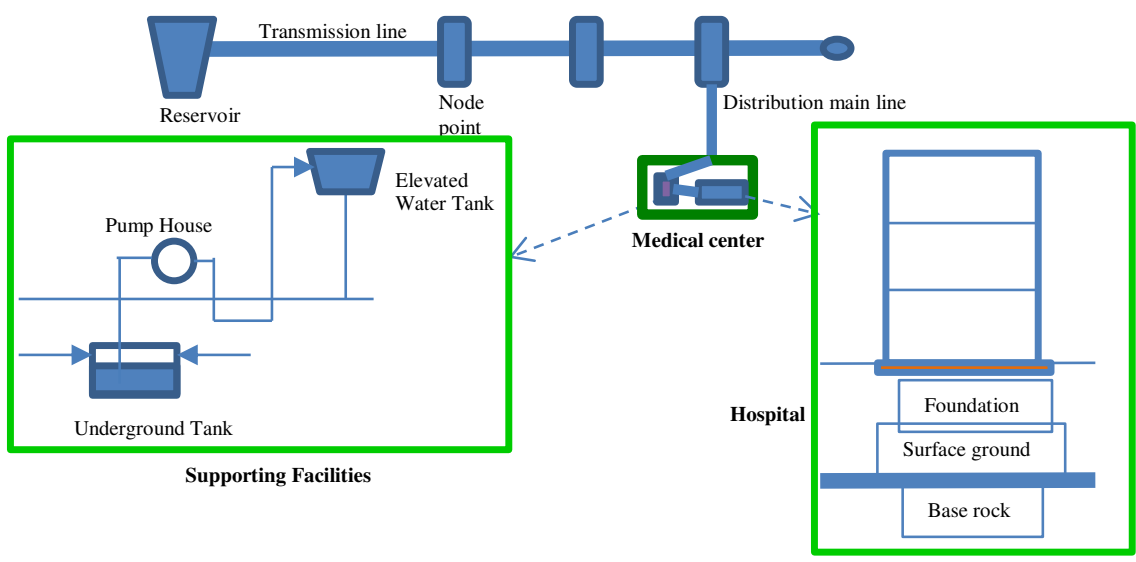

Figure 2. Schematic illustration of selected area of the study

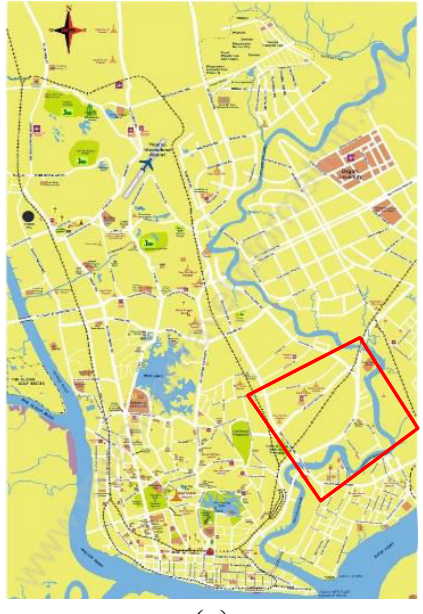

(a)

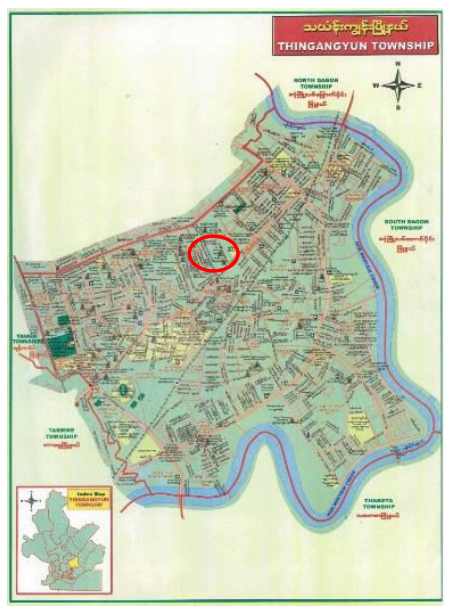

(b)

Figure 3. (a) Yangon map (Selected portion is Thingangyun township), (b) Thingangyun township (Selected portion is location of the selected hospital) 
The Third International Conference on Civil Engineering Research (ICCER)

August $1^{\text {st }}-2^{\text {nd }} 2017$, Surabaya - Indonesia

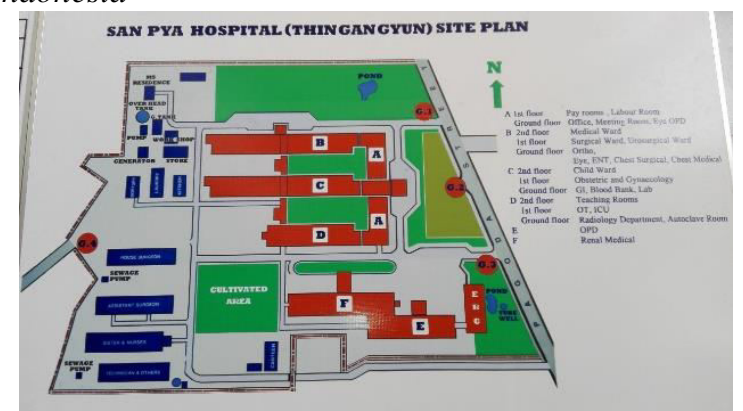

Figure 4. Site plan of Thingangyun (Sanpya) hospital

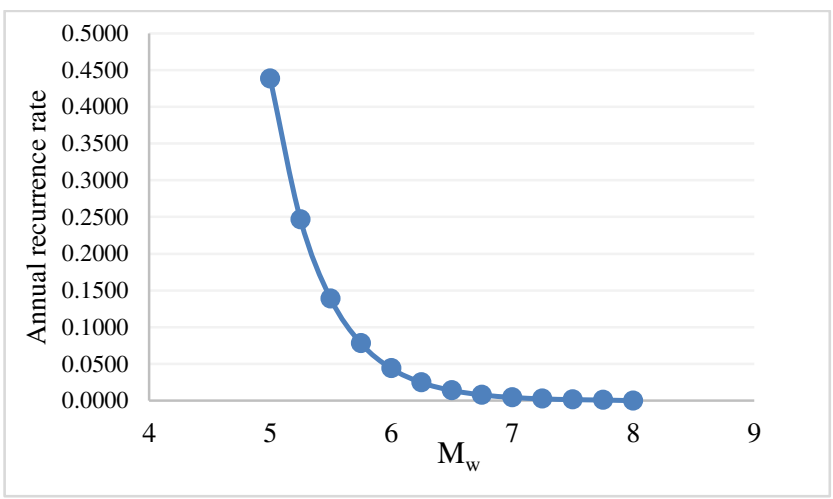

Figure 5. Illustrating the annual rate of exceedance of certain earthquake

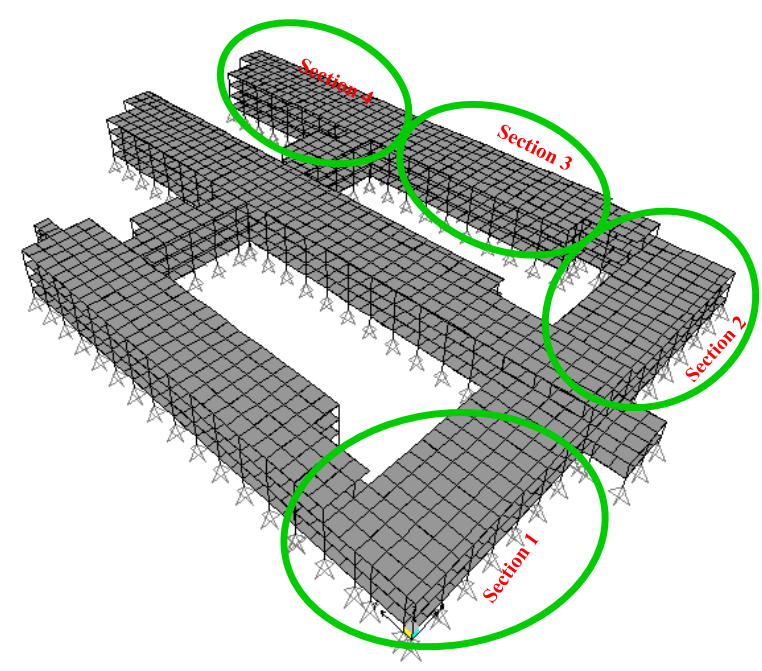

Figure 6. 3D View of Thingangyun Sanpya General Hospital

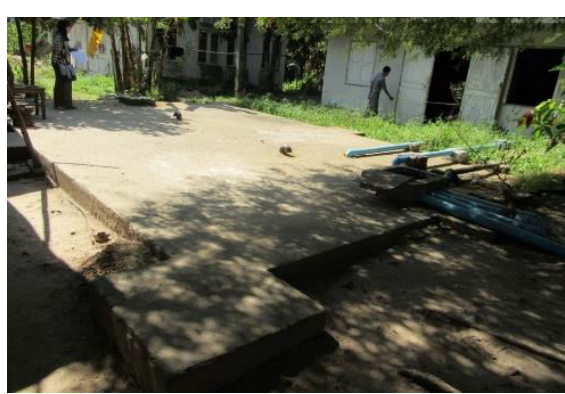

Existing structure

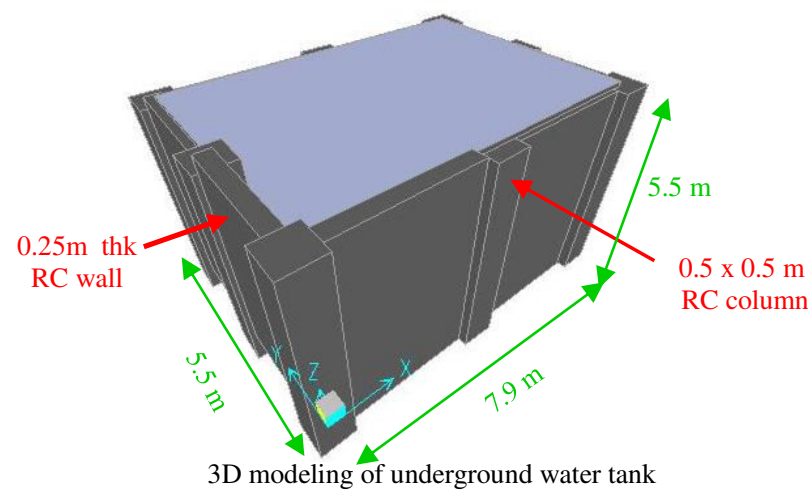

3D modeling of underground water tank

Figure 7. Modeling of underground water tank 1 
Regional Conference in Civil Engineering RCCE)

The Third International Conference on Civil Engineering Resec

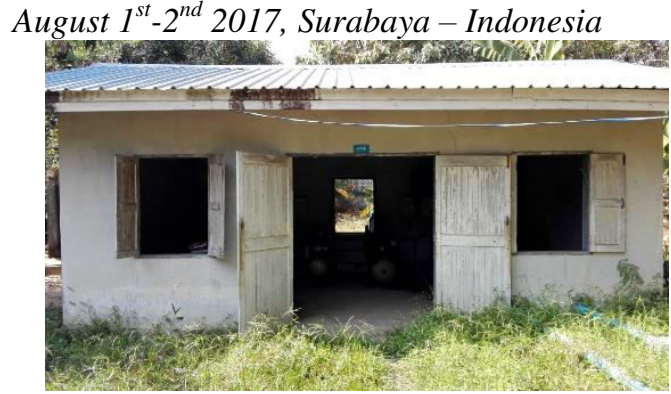

Existing structure

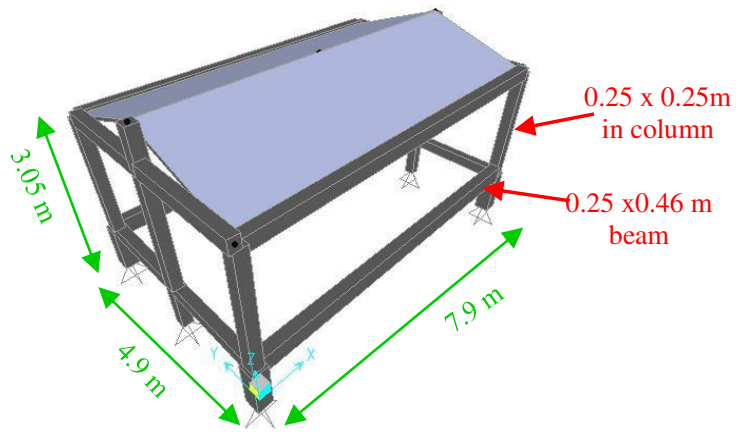

3D modeling of pump house

Figure 8. Modeling of pump house

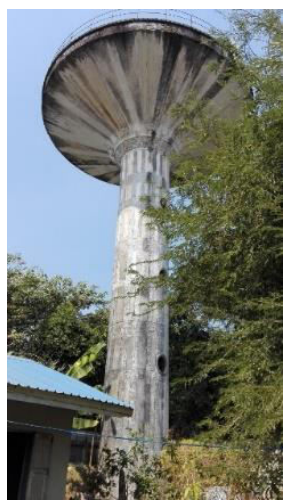

Existing structure

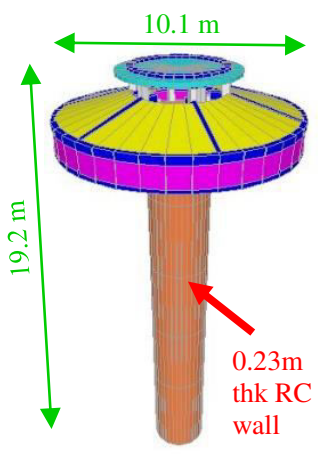

3D modeling of elevated water tank

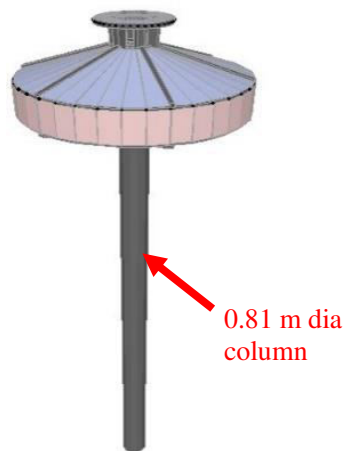

Equivalent frame modeling of elevated water tank

Figure 9. Modeling of elevated water tank

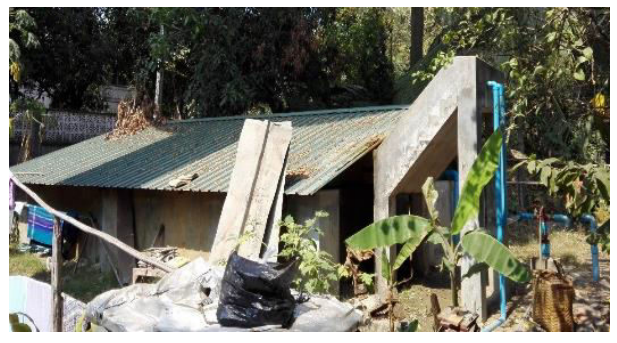

Existing structure

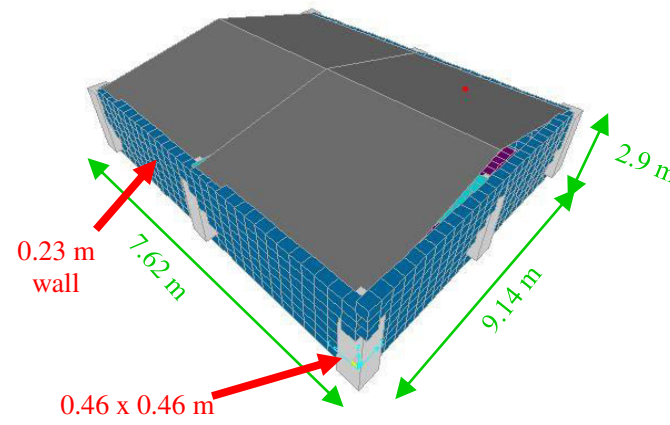

column

3D modeling of underground tank

Figure 10. Modeling of underground water tank 2
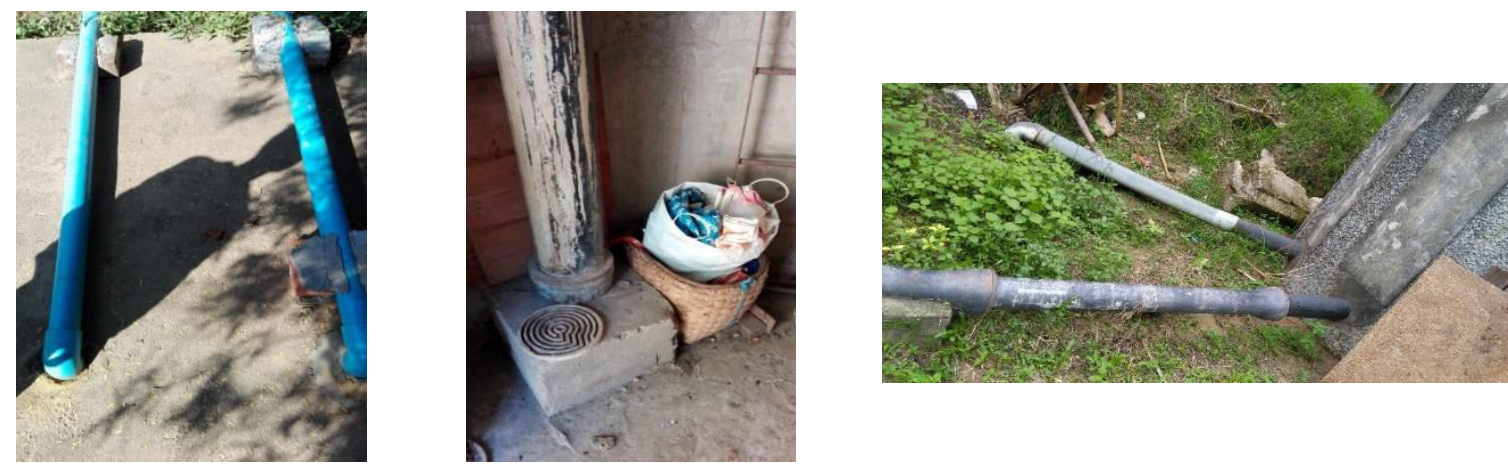

Figure 11. Existing Conditions of Some Pipe Segments and Pipe Joints 
The Third International Conference on Civil Engineering Research (ICCER)

August $1^{\text {st }}-2^{\text {nd }} 2017$, Surabaya - Indonesia

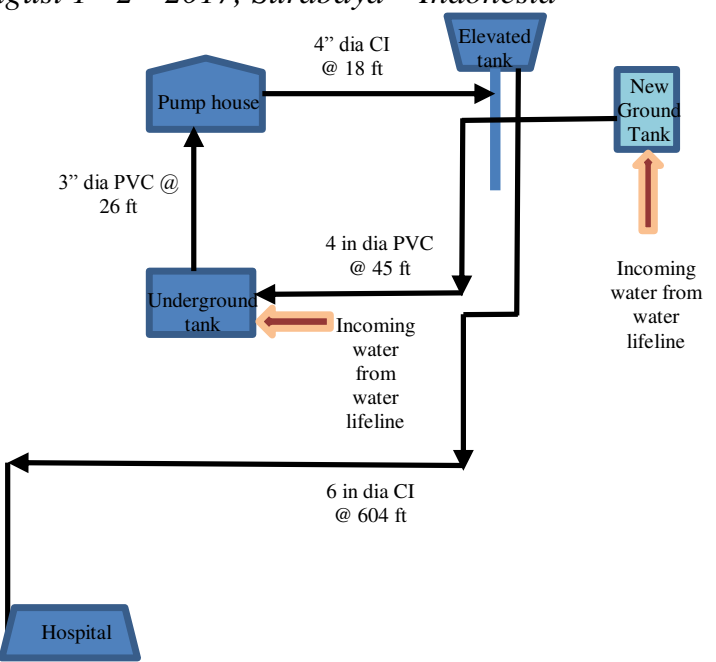

(a)

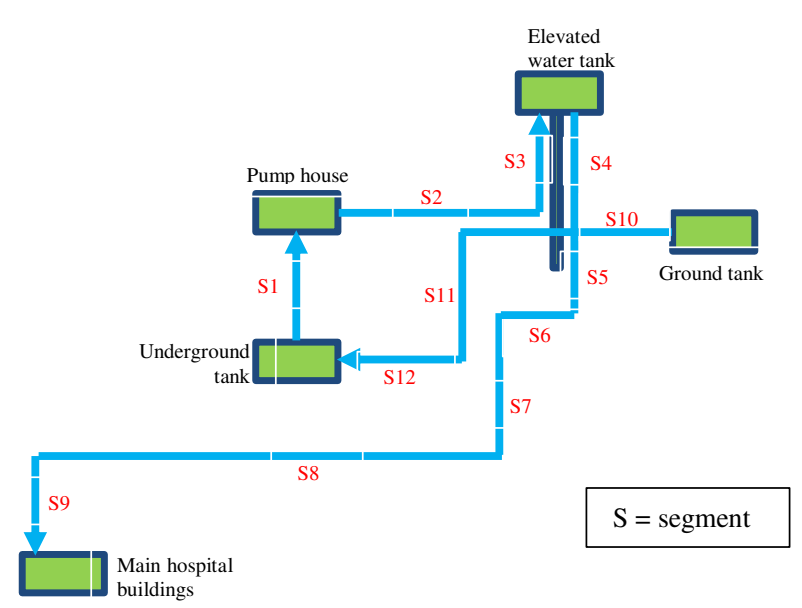

(b)

Figure 12. (a) Plan configuration of water supply system in the hospital; (b) Modelling of water supply system in the

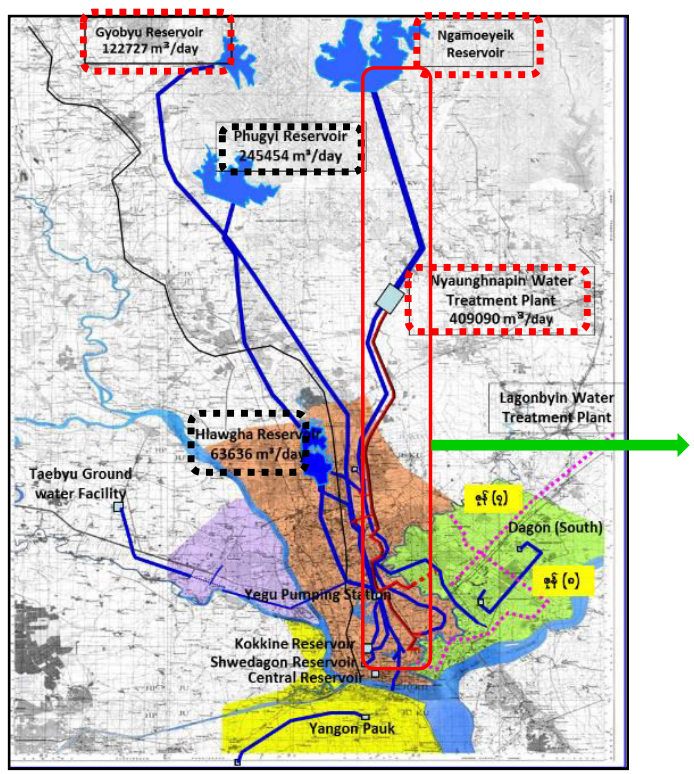

(a) hospital

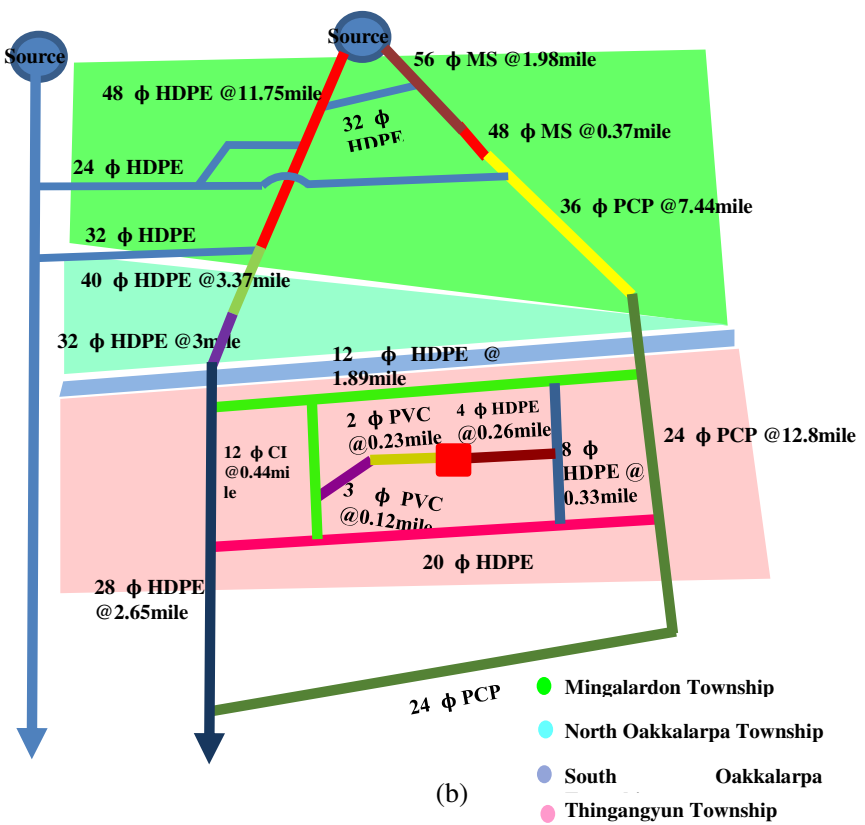

Figure 13. (a) Schematic configuration of existing water system of Yangon,

(b) Modelling of existing water supply system from Nyaung Hna Pin water treatment plant to Sanpya Hospital

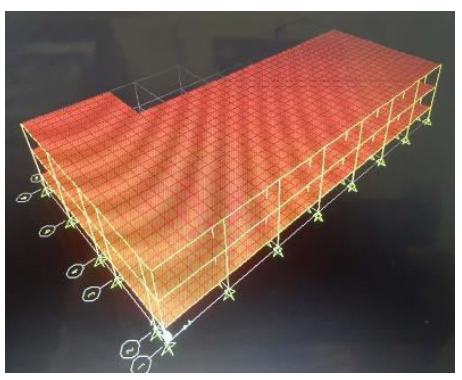

(a)

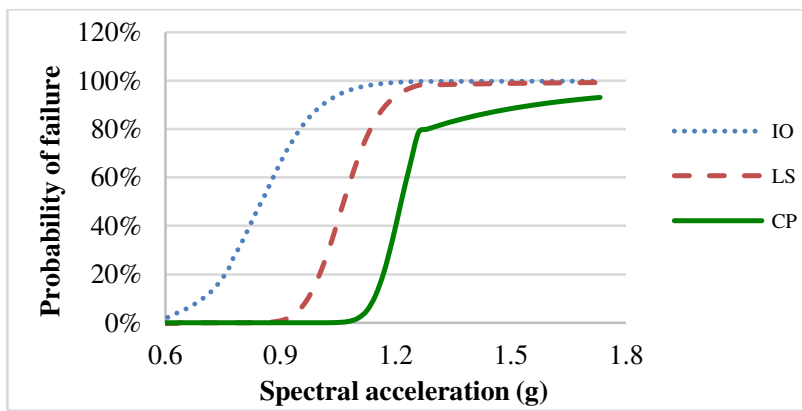

(b)

Figure 14. (a) Section 1 of main hospital building; (b) Fragility curves of section 1 for MOE, DBE and MCE levels 
The Third International Conference on Civil Engineering Research (ICCER)

August $1^{\text {st }}-2^{\text {nd }}$ 2017, Surabaya - Indonesia

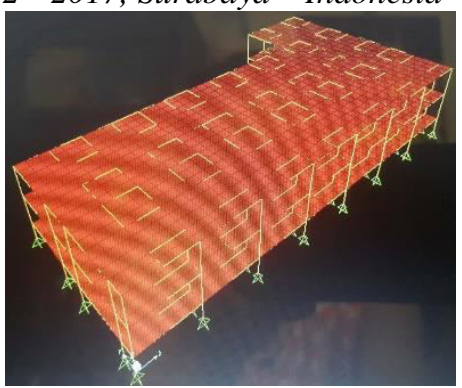

(a)

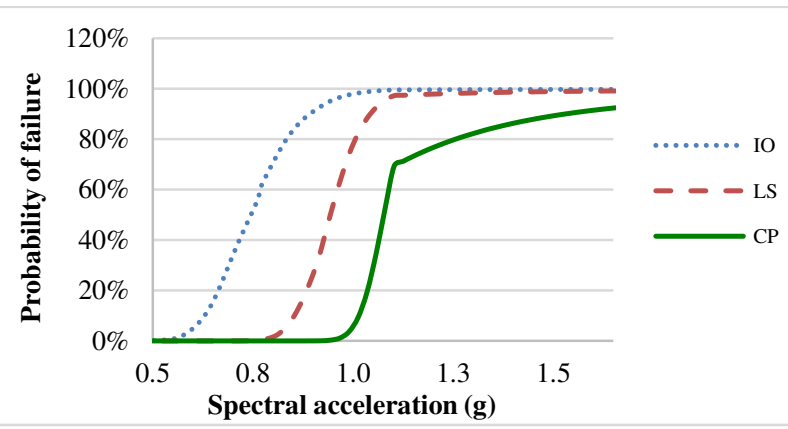

(b)

Figure 15. (a) Section 2 of main hospital building; (b) Fragility curves of section 2 for MOE, DBE and MCE levels

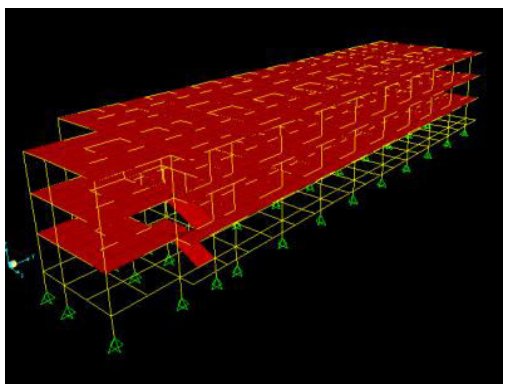

(a)

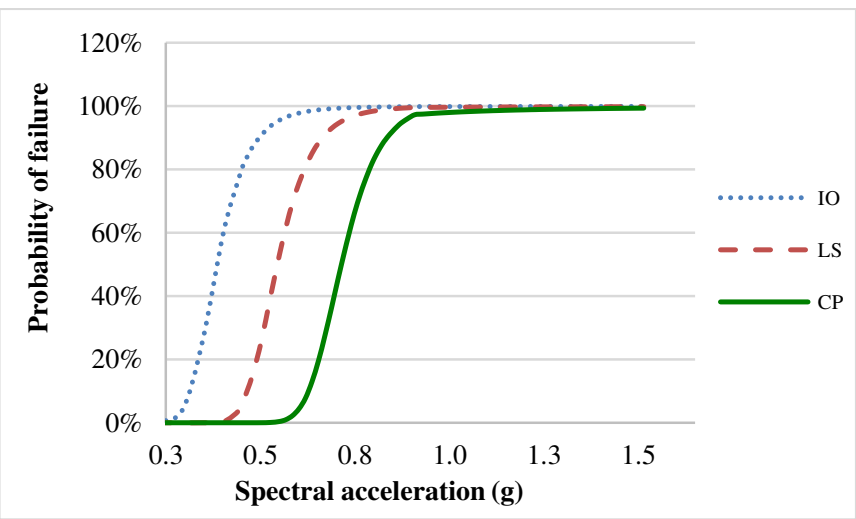

(b)

Figure 16. (a) Section 3 of main hospital building; (b) Fragility curves of section 3 for MOE, DBE and MCE levels

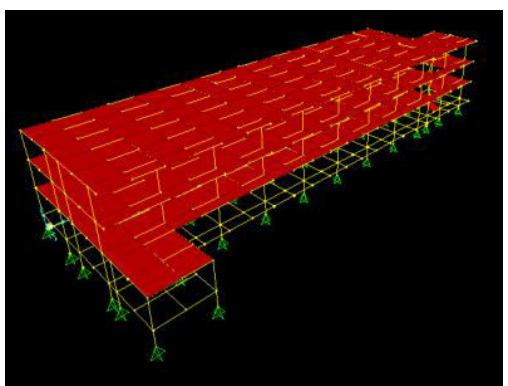

(a)

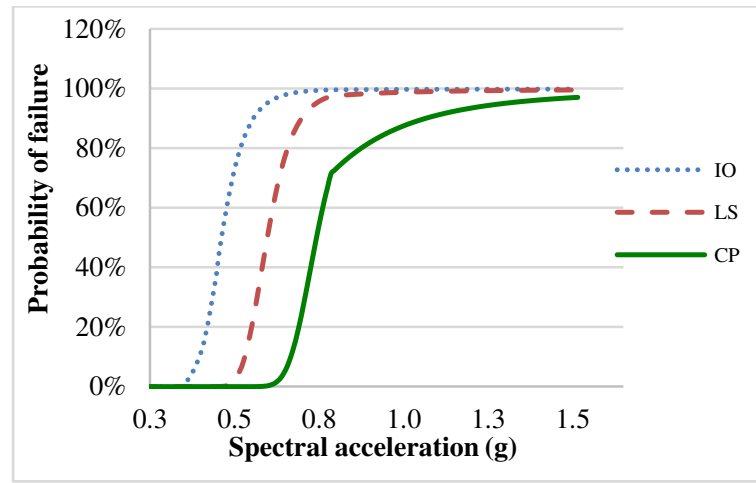

(b)

Figure 17. (a) Section 4 of main hospital building; (b) Fragility curves of section 4 for MOE, DBE and MCE levels

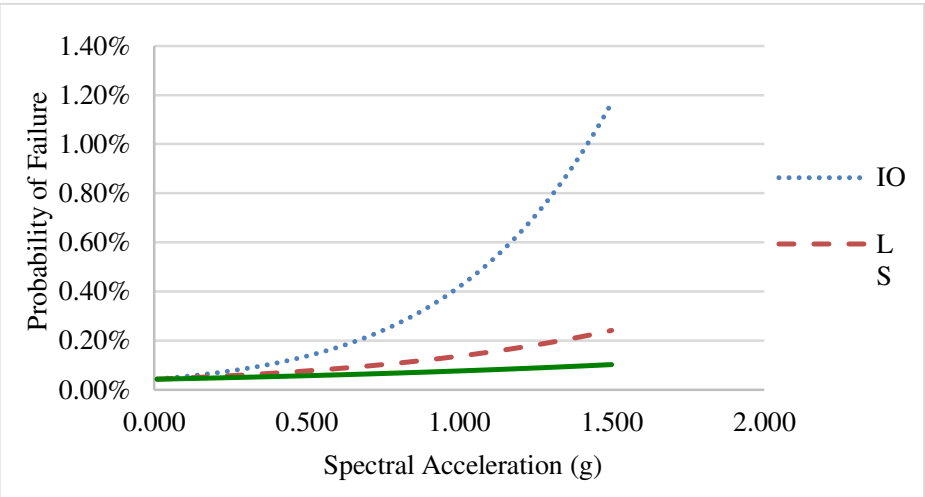

Figure 18. Fragility curves of underground water tank 1 
The Third International Conference on Civil Engineering Research (ICCER)

August $1^{\text {st }}-2^{\text {nd }}$ 2017, Surabaya - Indonesia

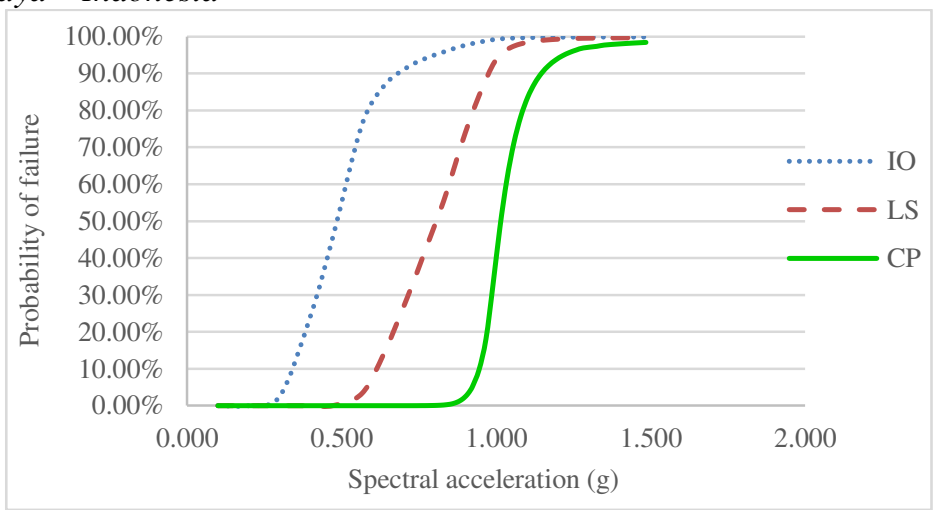

Figure 19. Fragility curves of pump house

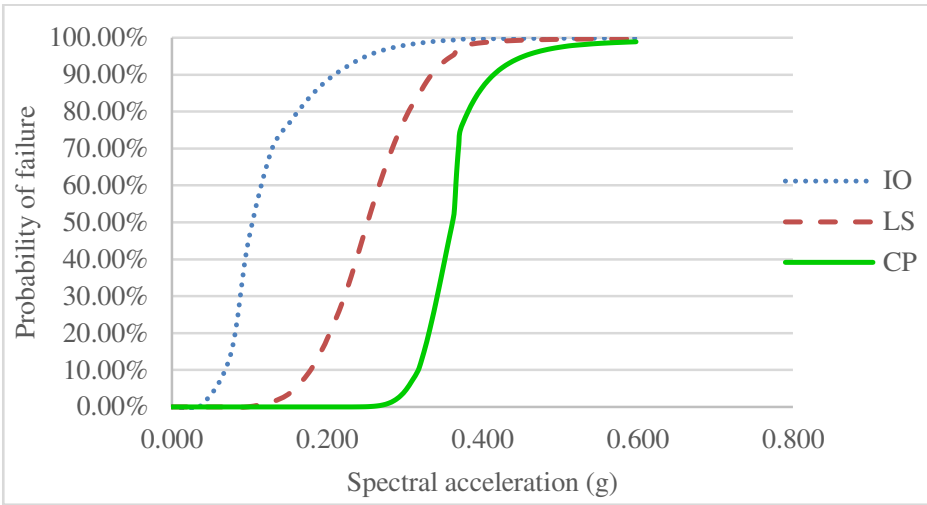

Figure 20. Fragility curves of elevated water tank

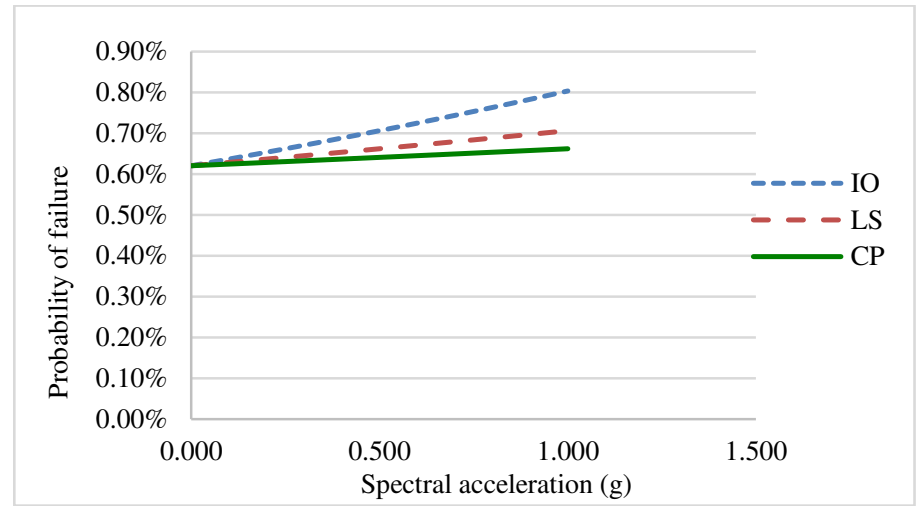

Figure 21. Fragility curves of underground water tank 2

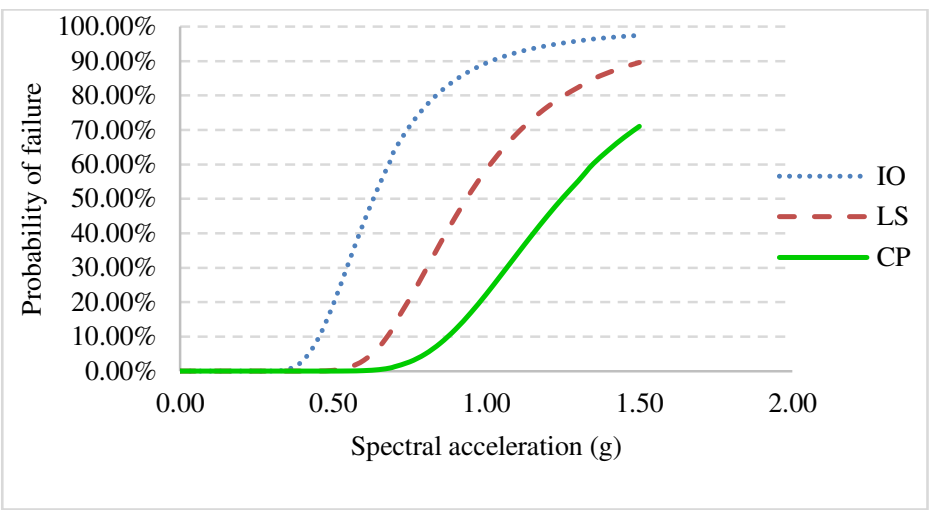

Figure 22. Fragility curves of pipe segment 1(PVC pipe) from internal water supply system 
The Third International Conference on Civil Engineering Research (ICCER)

August $1^{\text {st }}-2^{\text {nd }} 2017$, Surabaya - Indonesia

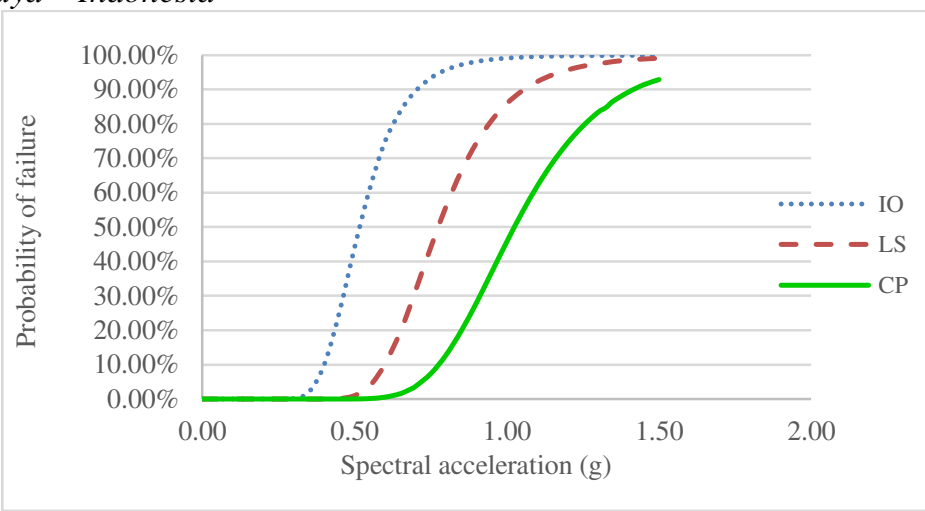

Figure 23. Fragility curves of pipe segment 3(CI pipe) from internal water supply system

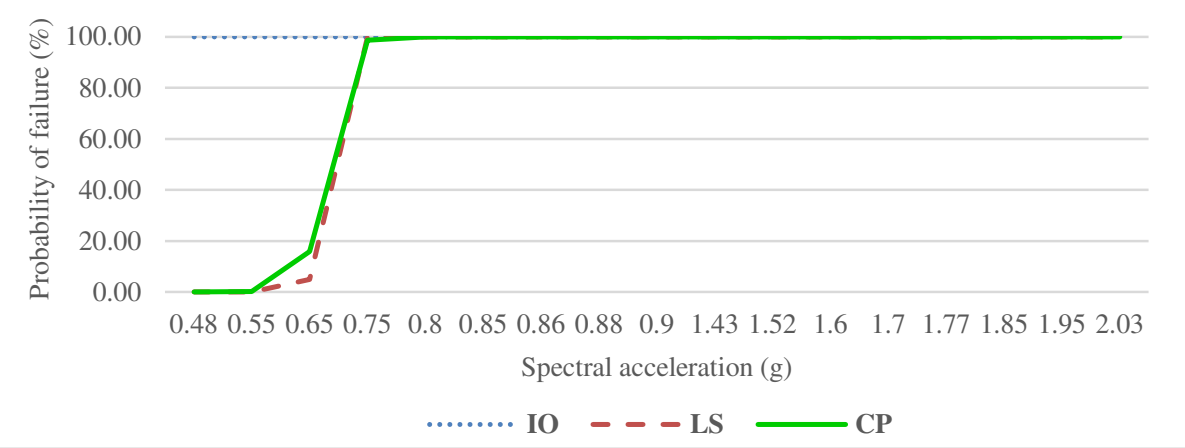

Figure 24. Fragility curves of 24" diameter PCP pipe at Thingangyun Township

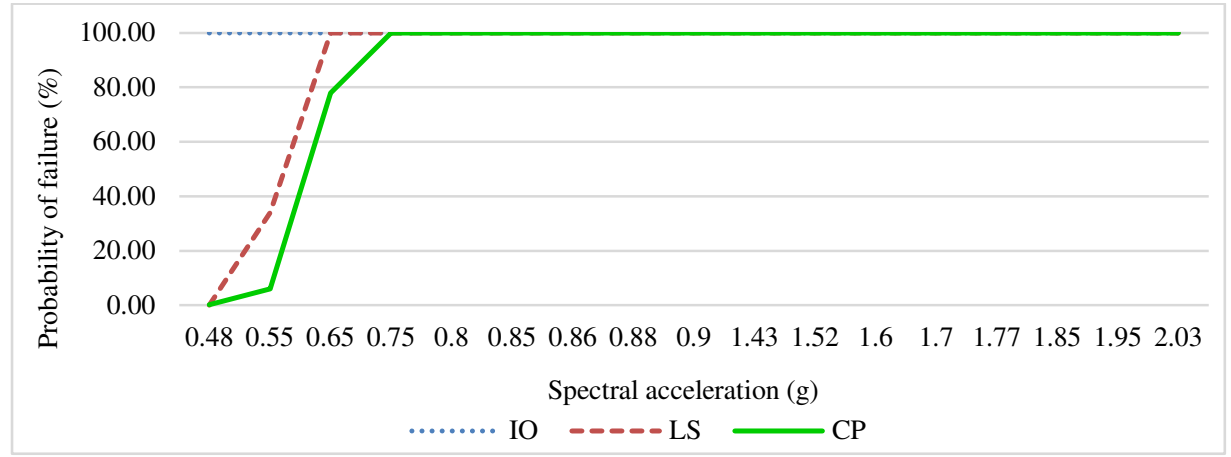

Figure 25. Fragility curves of 12" diameter CI pipe at Thingangyun Township

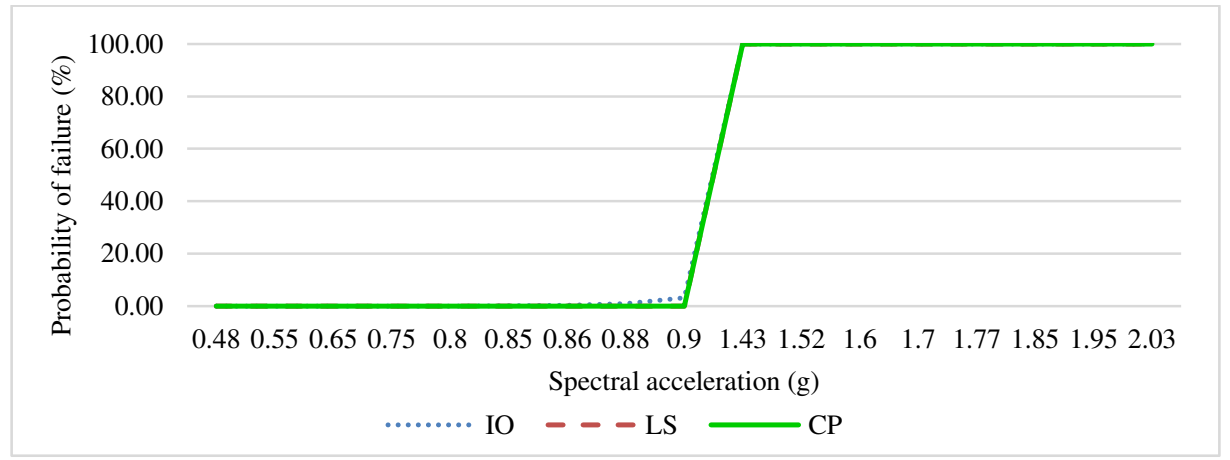

Figure 26. Fragility curves of 12" diameter HDPE pipe at Thingangyun Township 
Table 1. Seismic hazard analysis results

\begin{tabular}{ccccccc}
\hline Earthquakes & $\begin{array}{c}\text { Probability of } \\
\text { exceedence in 50 } \\
\text { years }\end{array}$ & $\begin{array}{c}\text { Return } \\
\text { Period } \\
\text { (years) }\end{array}$ & $\begin{array}{c}\text { Moment } \\
\text { Magnitude } \\
\mathrm{M}_{\mathrm{w}}\end{array}$ & $\begin{array}{c}(\mathrm{PGA})_{\mathrm{b}} \\
(\mathrm{g})\end{array}$ & $\mathrm{G}_{\mathrm{s}}$ & $\begin{array}{c}(\mathrm{PGA})_{\mathrm{s}} \\
(\mathrm{g})\end{array}$ \\
\hline MOE & $50 \%$ & 73 & 6.51 & 0.0959 & 1.62 & 0.1554 \\
DBE & $10 \%$ & 275 & 7.34 & 0.1957 & 1.66 & 0.3249 \\
MCE & $2 \%$ & 2475 & 7.87 & 0.3085 & 1.91 & 0.5892 \\
\hline
\end{tabular}

Table 2. Dimensions of buildings for case studies

\begin{tabular}{cccccc}
\hline Section & L(ft.) & B(ft.) & H(ft.) & L/B & $\begin{array}{c}\text { No. of } \\
\text { Stories }\end{array}$ \\
\hline 1 & 140 & 75 & 22 & 1.86 & 2 \\
2 & 140 & 75 & 22 & 1.86 & 2 \\
3 & 200 & 55 & 33 & 3.64 & 3 \\
4 & 200 & 55 & 33 & 3.64 & 3 \\
\hline
\end{tabular}

Table 3. Spectral velocities of MOE, DBE and MCE levels for four townships

\begin{tabular}{|c|c|c|c|c|}
\hline \multirow[b]{2}{*}{ EARTHQUAKE } & \multicolumn{4}{|c|}{ RESPONSE VELOCITY SPECTRUM $\left(S_{v}\right) \mathrm{m} / \mathrm{s}$} \\
\hline & Mingalardon & $\begin{array}{c}\text { North } \\
\text { Oakkalarpa }\end{array}$ & $\begin{array}{c}\text { South } \\
\text { Oakkalarpa }\end{array}$ & Thingangyun \\
\hline MOE & 0.366 & 0.366 & 0.366 & 0.361 \\
\hline DBE & 0.426 & 0.426 & 0.426 & 0.42 \\
\hline MCE & 1.090 & 1.090 & 1.090 & 1.075 \\
\hline
\end{tabular}

Table 4. Probability of Failure (Vulnerable conditions) of Each Structure

\begin{tabular}{|c|c|c|c|c|}
\hline \multirow[b]{2}{*}{ Structures } & \multirow{2}{*}{$\begin{array}{l}\text { Earthquake } \\
\text { Levels }\end{array}$} & \multicolumn{2}{|c|}{ Target Performance Levels } & \multirow[t]{2}{*}{$\mathrm{P}_{\mathrm{f}}(\%)$} \\
\hline & & Performances & Damage States & \\
\hline Main & MOE & IO & Minor wall cracks $<1 / 16$ in & 21.03 \\
\hline Building: & DBE & LS & Crushing \& flexural cracking & 0.83 \\
\hline Section 1 & MCE & $\mathrm{CP}$ & Serve boundary element damage & 91.77 \\
\hline Main & MOE & IO & Minor wall cracks $<1 / 16$ in & 55.6 \\
\hline Building: & DBE & LS & Crushing \& flexural cracking & 26.36 \\
\hline Section 2 & MCE & $\mathrm{CP}$ & Serve boundary element damage & 92.4 \\
\hline Main & MOE & IO & Minor wall cracks $<1 / 16$ in & 77.24 \\
\hline Building: & DBE & LS & Crushing \& flexural cracking & 96.97 \\
\hline Section 3 & MCE & $\mathrm{CP}$ & Serve boundary element damage & 99.36 \\
\hline Main & MOE & IO & Minor wall cracks $<1 / 16$ in & 35.77 \\
\hline Building: & DBE & LS & Crushing \& flexural cracking & 95.65 \\
\hline Section 4 & MCE & $\mathrm{CP}$ & Serve boundary element damage & 97.07 \\
\hline \multirow{3}{*}{$\begin{array}{l}\text { Under-ground } \\
\text { water tank }\end{array}$} & MOE & IO & Minor wall cracks $<1 / 16$ in & 0.17 \\
\hline & DBE & LS & Crushing \& flexural cracking & 0.09 \\
\hline & MCE & $\mathrm{CP}$ & Serve boundary element damage & 0.07 \\
\hline \multirow[t]{3}{*}{ Pump House } & MOE & IO & Hairline cracks \& limited yielding & 93.6 \\
\hline & DBE & LS & Beam damage, column shear cracks & 73.8 \\
\hline & MCE & $\mathrm{CP}$ & Hinge formations, splice failure & 97.3 \\
\hline \multirow{3}{*}{$\begin{array}{l}\text { Elevated water } \\
\text { tank }\end{array}$} & MOE & IO & Minor wall cracks $<1 / 16$ in & 87.4 \\
\hline & DBE & LS & Crushing \& flexural cracking & 88.2 \\
\hline & MCE & $\mathrm{CP}$ & Serve boundary element damage & 98.2 \\
\hline \multirow{3}{*}{$\begin{array}{l}\text { Ground water } \\
\text { tank }\end{array}$} & MOE & IO & Minor wall cracks $<1 / 16$ in & 0.69 \\
\hline & DBE & LS & Crushing \& flexural cracking & 0.64 \\
\hline & MCE & $\mathrm{CP}$ & Serve boundary element damage & 0.65 \\
\hline Water supply & MOE & IO & Small leakage of water from joint & 35 to 100 \\
\hline system in the & DBE & LS & Large leakage of water from joint & 14 to 100 \\
\hline campus & MCE & $\mathrm{CP}$ & The joint is pull-out & 34 to 100 \\
\hline Water lifeline & MOE & IO & Small leakage of water from joint & 100 \\
\hline
\end{tabular}




\begin{tabular}{ccccc}
\hline system & DBE & LS & Large leakage of water from joint & 100 \\
& MCE & CP & The joint is pull-out & 100 \\
\hline
\end{tabular}

\section{REFERENCES}

[1] T. K. Datta, "Seismic Analysis of Structures", Indian Institute of Technology, Delhi, India, 2010.

[2] Russell A. Green, William J. Hall, "An Overview of Selected Seismic Hazard Analysis Methodologies", University of Illinois at Urbana-Champaign, Urbana, Illinois, 1994.

[3] Myo Thant, Nwai Le' Ngal, Soe Thura Tun, Maung Thein, Win Swe, Than Myint, "Seismic Hazard Assessment for Myanmar", Myanmar Earthquake Committee (MEC), Myanmar Geosciences Society (MGS), 2012.

[4] Jack W. Baker, "An Introduction to Probabilistic Seismic Hazard Analysis", October 1, 2008.

[5] Computer and Structures Inc., "Pushover Analysis Manual in Structural Analysis Program 2000 Version 14.0.0", University Avenue Berkeley, California, 1995.

[5] International Conference of Building Officials, 1997, "Structural Engineering Design Provision", Volume 2, Uniform Building Code UBC-97.

[6] ATC 1996, "Seismic Evaluation and Retrofit of Concrete Buildings", Volume-1, ATC-40 Report, Applied Technology Council, Redwood City, California, 1996.

[7] FEMA 2000, "Prestandard and Commentary for the Seismic Rehabilitation of Buildings", FEMA 356, Federal Emergency and Management Agency, Washington D.C.

[8] NEHRP 1997, "Guidelines for Seismic Rehabilitation of Building", FEMA 273, Federal Emergency and Management Agency, Washington D.C.
[9] Kelly. T.E, "Performance Based Evaluation of Buildings", Holmes Consulting Group Ltd, Wellington, New Zealand, 2001.

[10] M. Hamada, Editor-in-Chief, "Critical Urban Infrastructure Handbook", Japan Society of Civil Engineers Critical Urban Infrastructure Committee.

[11] S. Tesfamariam, K. Goda, "Handbook of Seismic Risk Analysis and Management of Civil Infrastructure Systems", 2013.

[12] ACI Committee 318(1999), "Building Code Requirement for Structural Concrete", American Concrete Institute, Detroit, USA.

[13] Tang Aiping and OU Jinping Wen Aihua TAO Xiaxin, "Lifeline systems interaction and their seismic performance assessment", presented at $13^{\text {th }}$ World Conference on Earthquake Engineering, Vancouver, B.C., Canada, August 1-6, 2004, Paper No. 3437.

[14] Situation of water supply system of Yangon city and its future demand, Yangon City Development Committee. http://www.ycdc.gov.mm/ 